\title{
Riparian Land-Use Impacts on Stream Bank and Gully Erosion in Agricultural Watersheds: What We Have Learned
}

\author{
George N. Zaimes ${ }^{1, *}$, Mustafa Tufekcioglu ${ }^{2}$ and Richard C. Schultz ${ }^{3}$ \\ 1 Laboratory of Management and Control of Mountainous Waters, Department of Forestry and Natural \\ Environment, International Hellenic University, 1st km Drama- Microhoriou, Drama 66100, Greece \\ 2 Faculty of Forestry, Artvin Coruh University, Artvin 08000, Turkey \\ 3 Natural Resource Ecology and Management Department, Iowa State University, 339 Science Hall II, Ames, \\ IA 50011, USA \\ * Correspondence: zaimesg@teiemt.gr; Tel.: +30-25210-60416
}

Received: 21 May 2019; Accepted: 24 June 2019; Published: 28 June 2019

\begin{abstract}
Stream bank and gully erosion are major sources of nonpoint source pollutants, especially in landscapes dominated by agriculture. Implementation of upland conservation practices in landscapes dominated by agriculture reduces upland sediment transport more than water runoff, leading to excessive stream bank and gully erosion. This review focus on ten different studies conducted in streams in Iowa that investigated riparian land-use impacts on stream banks, gullies, and other riparian sediment sources (cattle loafing areas and cattle stream access points). The riparian land-uses investigated were riparian forest buffers; grass filters; continuous, rotational, and intensive rotational pastures; pastures with cattle fenced out of the stream; and row-cropped fields. Results of these studies indicate that maintaining perennial deep-rooted vegetation in riparian areas and excluding cattle from the stream channel stabilizes stream banks and gullies. Cattle loafing areas and cattle stream access points appear to also be important sediment sources. Re-establishing perennial riparian vegetation is a sustainable and cost-effective conservation practice because it reduces sediment in streams while maintaining the majority of the watershed in agricultural production. The limited available funds for the implementation of holistic watershed conservation practices suggest using targeted approaches, at the watershed scale, to improve conservation practice effectiveness.
\end{abstract}

Keywords: agricultural landscapes; conservation practices; cattle loafing areas; cattle stream access points

\section{Introduction}

Enhancing stream and gully channel stability has been a priority for decades with large amounts of money spent on watershed and stream restoration projects [1-3]. Natural stream bank and gully erosion can enhance biodiversity in riparian areas [4] and maintain the alluvial channel conveyance system and capacity [5]. In contrast, accelerated stream bank and gully erosion can increase sedimentation that degrades aquatic habitats, reduces water quality, and increases flooding leading to loss of life and property (agricultural land and structures) [6-8].

Stream bank and gully erosion are major sources of nonpoint source pollutants, such as sediment and nutrients, especially in regions dominated by agriculture, such as the Midwestern U.S. Excessive sediment and nutrient loading can: (a) reduce water quality, posing health risks to humans and requiring costly drinking water treatment; (b) kill livestock and wildlife; (c) degrade aquatic habitats by causing eutrophication that can kill aquatic species; (d) diminish recreational opportunities; (e) decrease navigational activities; and (f) reduce reservoir storage [9-15]. 
Fox et al. [3] reported that $7 \%-92 \%$ of the suspended sediment load in streams originates from stream bank and gully erosion. In studies conducted in the Midwestern U.S., stream banks contributed $23 \%-79 \%$ of the in-stream sediment load in Minnesota streams [16-19], $0 \%-81 \%$ in Wisconsin streams [20], and $23 \%-64 \%$ in Iowa streams [21-25]. These high sediment contributions from stream and gully banks are the result of the implementation of conservation practices to reduce nonpoint source pollutants originating from upland erosion and runoff $[26,27]$. While the sediments from surface runoff reaching the stream channel were substantially reduced, the amounts of water from surface runoff were not reduced to the same degree. This imbalance created a high sediment transport capacity that eroded the stored sediments in the floodplains and channels that were deposited during the 19th and 20th centuries [28]. In watersheds with significant hydrologic alteration, the major source of sediment in streams has shifted from uplands to gullies and stream channels [29-31].

The main reasons for the increase in the stream bank and gully erosion rates are anthropogenic activities that have resulted in the alteration of the natural geomorphologic dynamics of streams and rivers [19]. Such activities include land-use changes (e.g., increase in agricultural lands) in the riparian areas and at the watershed, infrastructure construction along the riverbanks, construction of bank revetments, reservoir construction, sand mining, urbanization, and channelization [32-34]. These anthropogenic activities can have significantly greater impacts on stream bank and gully erosion than natural events, such as floods and droughts, and in many cases can increase the intensities of these natural events.

The accelerated rates of stream bank and gully erosion indicate the need for conservation and protective efforts to eliminate the engineering, environmental, and socio-economic problems that have been created. Land-use, management practice, and vegetation cover in the riparian areas are of major importance to stream bank and gully erosion rates. The purpose of this review was to reach general conclusions by assessing, comparing, and summarizing case studies dealing with stream bank and gully erosion and other potential sediment sources of riparian areas in Iowa, USA. Major conservation practices in riparian areas were compared to common agricultural practices and recently adopted grazing practices. This review provides insights on best management practices to mitigate stream bank and gully erosion that are applicable in landscapes dominated by agriculture.

\section{Materials and Methods}

\subsection{Studies Reviewed}

Ten erosion studies along perennial stream reaches located in regions of Iowa, USA conducted during the last two decades by the Agroforestry Group at Iowa State University were reviewed. Details of the ten studies can be found in Table 1. The natural Iowa vegetation (prairies and wetlands) has been altered to row crop agriculture and grass pastures more extensive than in any other state in the US [35,36]. In Iowa and other states dominated by agriculture, most streams are in Stage III [37] with unstable banks highly susceptible to erosion [26,28,38]. 
Table 1. Case study characteristics, study periods, and variables measured or collected.

\begin{tabular}{|c|c|c|c|c|c|c|}
\hline $\begin{array}{l}\text { Case Study Number, } \\
\text { Name, and } \\
\text { Reference }\end{array}$ & $\begin{array}{l}\text { Iowa Region } \\
\text { (Landform) }\end{array}$ & $\begin{array}{l}\text { Number and Order of } \\
\text { Stream Reaches } \\
\text { (Strahler System [39]) }\end{array}$ & $\begin{array}{c}\text { Riparian } \\
\text { Land-Uses * }\end{array}$ & Data Years & Stream Bank Variables (Units) & Other Variables (Units) \\
\hline $\begin{array}{c}\text { 1. Bear Creek-Pins } \\
{[40,41]}\end{array}$ & $\begin{array}{l}\text { Central (Des Moines } \\
\text { Lobe) }\end{array}$ & $\begin{array}{l}\text { Single 2nd order stream } \\
\text { reach }\end{array}$ & $\begin{array}{l}\text { RF } \\
\text { CP } \\
\text { RC }\end{array}$ & $\begin{array}{l}1999 \\
2000 \\
2001 \\
2002\end{array}$ & $\begin{array}{c}\text { Erosion or Deposition Rates }(\mathrm{mm}) \\
\text { Severely Eroding Lengths }(\%) \\
\text { Severely Eroding Areas }\left(\mathrm{m}^{2} \mathrm{~km}^{-1}\right) \\
\text { Soil Bulk Density }\left(\mathrm{g} \mathrm{cm}^{-3}\right)(1999 \& \text { 2002) } \\
\text { Soil Loss }\left(\mathrm{Mg} \mathrm{km}^{-1} \text { year }^{-1}\right)\end{array}$ & Precipitation Data $\left(\mathrm{mm}\right.$ year $\left.^{-1}\right)$ \\
\hline $\begin{array}{l}\text { 2. Bear Creek-PEEPs } \\
\text { [42] }\end{array}$ & $\begin{array}{l}\text { Central (Des Moines } \\
\text { Lobe) }\end{array}$ & $\begin{array}{l}\text { Single 2nd order stream } \\
\text { reach }\end{array}$ & $\begin{array}{l}\text { RF } \\
\text { GF } \\
\mathrm{CP}\end{array}$ & $\begin{array}{l}2002-2003 \\
2003 \\
2002-2003\end{array}$ & $\begin{array}{l}\text { Erosion or Deposition Rates }(\mathrm{mm}), \\
\text { Severely Eroding Lengths }(\%), \\
\text { Severely Eroding Areas }\left(\mathrm{m}^{2} \mathrm{~km}^{-1}\right) \\
\text { Soil Loss }\left(\mathrm{Mg} \mathrm{km}^{-1} \mathrm{year}^{-1}\right) \\
\text { Erosion \& Deposition events }(\#) \\
\text { Major Erosion \& Deposition events (\#) }\end{array}$ & $\begin{array}{c}\text { Precipitation Data }\left(\mathrm{mm} \mathrm{year}^{-1}\right) \\
\text { Stream Flow Data }\left(\mathrm{m}^{3} \mathrm{~s}^{-1} \text { year }^{-1}\right) \\
\text { Soil Bulk Density }\left(\mathrm{g} \mathrm{cm}^{-3}\right)(\text { only 2002) }\end{array}$ \\
\hline $\begin{array}{l}\text { 3. Walnut Creek } \\
{[25,43]}\end{array}$ & $\begin{array}{l}\text { Southeast (Southern } \\
\text { Iowa Drift Plain) }\end{array}$ & $\begin{array}{l}\text { Single 3rd order stream } \\
\text { reach }\end{array}$ & $\begin{array}{l}\text { RF } \\
\text { GF } \\
\text { CP }\end{array}$ & $\begin{array}{l}2005 \\
2006 \\
2007-2008 \\
2009 \\
2010 \\
2011\end{array}$ & $\begin{array}{c}\text { Erosion or Deposition Rates }(\mathrm{mm}), \\
\text { Severely Eroding Lengths }(\%)(2004 \& 2010) \\
\text { Soil Loss }\left(\mathrm{Mg} \mathrm{km}^{-1} \text { year }^{-1}\right) \text { (only for the entire } \\
\text { reach) }\end{array}$ & $\begin{array}{c}\text { Precipitation Data }\left(\mathrm{mm} \mathrm{year}^{-1}\right) \\
\text { Stream Flow Data }\left(\mathrm{m}^{3} \mathrm{~s}^{-1} \text { year }^{-1}\right) \\
\text { Soil Bulk Density }\left(\mathrm{g} \mathrm{cm}^{-3}\right)\left(\text { only }^{2005)}\right. \\
\left.\text { Stream TSS Load (tons year }{ }^{-1}\right)(\text { only for the } \\
\text { entire reach) }\end{array}$ \\
\hline 4. Squaw Creek [43] & $\begin{array}{l}\text { Southeast (Southern } \\
\text { Iowa Drift) }\end{array}$ & $\begin{array}{l}\text { Single 3rd order stream } \\
\text { reach }\end{array}$ & $\begin{array}{l}\mathrm{RF} \\
\mathrm{RC}\end{array}$ & 2004 & Severely Eroding Lengths (\%) & \\
\hline $\begin{array}{l}\text { 5. Rathbun Lake } \\
\text { Watershed [44,45] }\end{array}$ & $\begin{array}{l}\text { Southeast (Southern } \\
\text { Iowa Drift Plain) }\end{array}$ & $\begin{array}{l}\text { Multiple (thirteen } \\
\text { 1st-3rd order) reaches } \\
\text { in a watershed }\end{array}$ & $\begin{array}{l}\text { GF } \\
\mathrm{CP}\end{array}$ & $\begin{array}{l}2006 \\
2007 \\
2008 \\
2009\end{array}$ & $\begin{array}{c}\text { Erosion or Deposition Rates }(\mathrm{mm}), \\
\text { Severely Eroding Lengths }(\%) \text { (only 2006) } \\
\text { Severely Eroding Areas }\left(\mathrm{m}^{2} \mathrm{~km}^{-1}\right) \text {, (only 2006) } \\
\text { Soil Loss }\left(\mathrm{Mgs} \mathrm{km}^{-1} \mathrm{year}^{-1}\right) \\
\text { Soil Bulk Density }\left(\mathrm{g} \mathrm{cm}^{-3}\right)\end{array}$ & $\begin{array}{c}\text { Precipitation Data }\left(\mathrm{mm} \mathrm{year}^{-1}\right) \\
\text { Stream Stage Data }\left(\mathrm{cm}^{-}\right) \\
\text {Riparian Area Soil Bulk Density }\left(\mathrm{g} \mathrm{cm}^{-3}\right) \\
\text { Stream Order, } \\
\text { Bed Slope }(\%) \\
\text { Sinuosity } \\
\text { Stocking Rates }\left(\mathrm{Lu} \mathrm{d} \mathrm{m}^{-1}\right)\end{array}$ \\
\hline 6. NE Region [46-48] & $\begin{array}{l}\text { Northeast (Paleozoic } \\
\text { Plateau and Iowan } \\
\text { Surface) }\end{array}$ & $\begin{array}{l}\text { Multiple (ten } 1 \text { st-3rd } \\
\text { order) reaches in a } \\
\text { region }\end{array}$ & $\begin{array}{l}\text { RF } \\
\text { FP } \\
\text { IP } \\
\text { CP }\end{array}$ & $\begin{array}{l}2002 \\
2003 \\
2004\end{array}$ & $\begin{array}{l}\text { Erosion or Deposition Rates (mm), } \\
\text { Severely Eroding Lengths (\%) (only 2004) } \\
\text { Severely Eroding Areas }\left(\mathrm{m}^{2} \mathrm{~km}^{-1}\right) \text { (only 2004) } \\
\text { Soil Bulk Density }\left(\mathrm{g} \mathrm{cm}^{-3}\right) \text { (only 2004) } \\
\text { Soil Loss }\left(\mathrm{Mg} \mathrm{km}^{-1} \text { year }^{-1}\right)\end{array}$ & $\begin{array}{c}\text { Precipitation Data }\left(\mathrm{mm} \mathrm{year}^{-1}\right) \\
\text { Riparian Soil Bulk Density }\left(\mathrm{g} \mathrm{cm}^{-3}\right)(\text { only } 2004) \\
\text { Number of gullies }\left(\# \mathrm{~km}^{-1}\right) \text { (only 2004) } \\
\text { Cattle access points }\left(\mathrm{km}^{-1}\right) \text { (only 2004) } \\
\text { Length of all gullies }\left(\mathrm{m} \mathrm{km}^{-1}\right)(\text { only 2004) } \\
\text { Bed Substrate }(\%)\left(\mathrm{only}^{2004)}\right. \\
\text { Stream Water TSS }\left(\mathrm{mg} \mathrm{L}^{-1}\right)\end{array}$ \\
\hline
\end{tabular}


Table 1. Cont

\begin{tabular}{|c|c|c|c|c|c|c|}
\hline $\begin{array}{c}\text { Case Study Number, } \\
\text { Name, and } \\
\text { Reference }\end{array}$ & $\begin{array}{l}\text { Iowa Region } \\
\text { (Landform) }\end{array}$ & $\begin{array}{l}\text { Number and Order of } \\
\text { Stream Reaches } \\
\text { (Strahler System [39]) }\end{array}$ & $\begin{array}{c}\text { Riparian } \\
\text { Land-Uses * }\end{array}$ & Data Years & Stream Bank Variables (Units) & Other Variables (Units) \\
\hline 7. CE Region [46-49] & $\begin{array}{l}\text { Central (Des Moines } \\
\text { Lobe) }\end{array}$ & $\begin{array}{l}\text { Multiple (ten 1st-3rd } \\
\text { order) reaches in a } \\
\text { region }\end{array}$ & $\begin{array}{l}\text { RF } \\
\text { GF } \\
\text { RP } \\
\text { CP } \\
\text { RC }\end{array}$ & $\begin{array}{l}2002 \\
2003 \\
2004\end{array}$ & $\begin{array}{l}\text { Erosion or Deposition Rates (mm), } \\
\text { Severely Eroding Lengths (\%) (only 2004) } \\
\text { Severely Eroding Areas }\left(\mathrm{m}^{2} \mathrm{~km}^{-1}\right) \text { (only 2004) } \\
\text { Soil Bulk Density }\left(\mathrm{g} \mathrm{cm}^{-3}\right) \text { (only 2004) } \\
\text { Soil Loss }\left(\mathrm{Mg} \mathrm{km}^{-1} \text { year }^{-1}\right)\end{array}$ & $\begin{array}{c}\text { Precipitation Data }\left(\mathrm{mm} \mathrm{year}^{-1}\right) \\
\text { Riparian Soil Bulk Density }\left(\mathrm{g} \mathrm{cm}^{-3}\right) \text { (only 2004) } \\
\text { Number of gullies }\left(\# \mathrm{~km}^{-1}\right)(\text { only 2004) } \\
\text { Cattle access points }\left(\# \mathrm{~km}^{-1}\right) \text { (only 2004) } \\
\text { Length of all gullies }\left(\mathrm{m} \mathrm{km}^{-1}\right)(\text { only 2004) } \\
\text { Bed Substrate }(\%)\left(\mathrm{only}^{2004)}\right. \\
\text { Stream Water TSS }\left(\mathrm{mg} \mathrm{L}^{-1}\right)\end{array}$ \\
\hline 8. SE Region [46-49] & $\begin{array}{l}\text { Southeast (Southern } \\
\text { Iowa Drift Plain) }\end{array}$ & $\begin{array}{l}\text { Multiple (ten 1st-3rd } \\
\text { order) reaches in a } \\
\text { region }\end{array}$ & $\begin{array}{l}\text { GF } \\
\text { FP } \\
\text { IP } \\
\text { RP } \\
\text { CP }\end{array}$ & $\begin{array}{l}2002 \\
2003 \\
2004\end{array}$ & $\begin{array}{c}\text { Erosion or Deposition Rates (mm), } \\
\text { Severely Eroding Lengths (\%) (only 2004) } \\
\text { Severely Eroding Areas }\left(\mathrm{m}^{2} \mathrm{~km}^{-1}\right) \text { (only 2004) } \\
\text { Soil Bulk Density }\left(\mathrm{g} \mathrm{cm}^{-3}\right) \text { (only 2004) } \\
\text { Soil Loss }\left(\mathrm{Mg} \mathrm{km}^{-1} \text { year }^{-1}\right)\end{array}$ & $\begin{array}{c}\text { Precipitation Data }\left(\mathrm{mm} \mathrm{year}^{-1}\right) \\
\text { Riparian Soil Bulk Density }\left(\mathrm{g} \mathrm{cm}^{-3}\right) \text { (only 2004) } \\
\text { Number of gullies }\left(\# \mathrm{~km}^{-1}\right) \text { (only 2004) } \\
\text { Cattle access points }\left(\# \mathrm{~km}^{-1}\right) \text { (only 2004) } \\
\text { Length of all gullies }\left(\mathrm{m} \mathrm{km}^{-1}\right)(\text { only 2004) } \\
\text { Bed Substrate }(\%)\left(\mathrm{only}^{2004)}\right. \\
\text { Stream Water TSS }\left(\mathrm{mg} \mathrm{L}^{-1}\right)\end{array}$ \\
\hline $\begin{array}{l}\text { 9. SE Region-Gully } \\
\text { [50] }\end{array}$ & $\begin{array}{l}\text { Southeast (Southern } \\
\text { Iowa Drift Plain } \\
\text { landform) }\end{array}$ & $\begin{array}{l}\text { Multiple (three } \\
\text { 2nd-3rd) reaches in a } \\
\text { region }\end{array}$ & $\begin{array}{l}\text { IP } \\
\text { RP } \\
\text { CP }\end{array}$ & 2004 & $\begin{array}{c}\text { Erosion or Deposition Rates (mm), } \\
\text { Severely Eroding Lengths (\%) (only 2004) } \\
\text { Severely Eroding Areas }\left(\mathrm{m}^{2} \mathrm{~km}^{-1}\right) \text { (only 2004) } \\
\text { Soil Bulk Density }\left(\mathrm{g} \mathrm{cm}^{-3}\right)(\text { only 2004) } \\
\text { Soil Loss }\left(\mathrm{Mg} \mathrm{km}^{-1} \text { year }^{-1}\right)\end{array}$ & $\begin{array}{l}\text { Precipitation Data }\left(\mathrm{mm} \mathrm{year}^{-1}\right) \text { Riparian Soil } \\
\text { Bulk Density }\left(\mathrm{g} \mathrm{cm}^{-3}\right)(\text { only 2004) } \\
\text { Gully Erosion Rates }(\mathrm{mm}) \\
\text { Gully Severely Eroding Lengths }(\%) \text { (only 2004) } \\
\text { Gully Severely Eroding Areas }\left(\mathrm{m}^{2} \mathrm{~km}^{-1}\right) \text { (only } \\
\text { 2004) } \\
\left.\text { Gully Soil Loss (tons km }{ }^{-1} \text { year }^{-1}\right)\end{array}$ \\
\hline $\begin{array}{l}\text { 10. Rainfall Simulator } \\
\text { [51] }\end{array}$ & $\begin{array}{l}\text { Northeast } \\
\text { Central } \\
\text { Southeast }\end{array}$ & $\begin{array}{l}\text { Multiple (nine 1st-3rd } \\
\text { order) reaches in a } \\
\text { region }\end{array}$ & $\begin{array}{l}\text { IP } \\
\text { RP } \\
\text { CP }\end{array}$ & 2005 & & $\begin{array}{c}\text { Stocking Rates (cow-day ha }{ }^{-1} \mathrm{~m}^{-1} \mathrm{year}^{-1} \text { ) } \\
\text { Loafing areas }(\%) \\
\text { Cattle Access Areas }(\%) \\
\text { Surface runoff }\left(1 / 0.5 \mathrm{~m}^{2}\right) \\
\text { Surface runoff TSS concentration }\left(\mathrm{g} \mathrm{L} \mathrm{L}^{-1}\right) \\
\text { Surface runoff soil loss }(\mathrm{kg} / \mathrm{km}, \mathrm{kg} / \mathrm{ha})\end{array}$ \\
\hline
\end{tabular}




\subsection{Riparian Land-Uses}

Seven different riparian land-uses were investigated. The first two were conservation practices: (a) riparian forest buffers (RF) and (b) grass filters (GF). The selected RF reaches were vegetated by zones of grasses, shrubs, and trees from the crop-field border to the stream edge [52]. In the GF reaches, riparian vegetation was primarily introduced cool-season grasses [53]. The reaches along annual row cropped fields (RC) had soybeans (Glycine max (L.) Merr.) and maize (Zea mays L.) grown in alternating years right up to the bank edge or with narrow strips of weeds and/or grasses along the banks. Almost all pasture reaches selected had cool-season grasses and forbs that were grazed by beef cattle from May till November (some year-round). In continuous grazed pastures (CP), cattle had full access to the entire stream channel and pasture. Both rotational grazed pastures (RP) and intensive rotational grazed pastures (IP) separated the pasture into smaller sections, the paddocks. The difference was that RP had fewer paddocks (2-3) than the IP (>6) [54]. Finally, there were reaches that were fenced, and the cattle had no access to the channel (FP).

\subsection{Methods}

The methods used are briefly described as follows. Details on the application of the methods can be found in the specific study publication (see Table 1).

\subsubsection{Stream Bank Annual Erosion Rates}

Two different methods were used to measure stream bank annual erosion rates. Seven of the studies $(1,3,5,6,7,8$, and 9; Table 1) [25,40,41,43,45,48,49] utilized erosion pins [51]. Only Study 2 (Table 1) [42] utilized photo-electronic erosion pins (PEEPs). Both methods have been used in many studies with good results when precision of the bank erosion rates are required $[55,56]$. The erosion pin plots were placed on severely eroding stream banks [57]. The bank rate of change was estimated by subtracting each measurement on the erosion pin from the previous measurement. Positive differences indicated bank erosion, while negative differences indicated bank deposition. Depending on the study, pins were measured monthly, bimonthly, seasonally, or yearly.

PEEPs record bank erosion and deposition rates continuously during the daytime [58,59]. Two erosion PEEP plots were placed on severely eroding stream banks. One of the plots was on a north-facing bank (north-bank) and the other on a south-facing bank (south-bank). Each plot included two PEEPs that were inserted perpendicularly at $1 / 3$ (top-bank, slope $>80 \%$ ) and $2 / 3$ (bottom-bank, slope $<60 \%$ ) of the bank height.

\subsubsection{Stream Bank Erosion and Deposition Events}

Continuous daytime measurements recorded by the PEEPs (Study 2) [42] provided the exact time and number of erosion and deposition events. The major erosion (rates $>30 \mathrm{~mm} \mathrm{day}^{-1}$ ) and deposition (rates $>20 \mathrm{~mm}$ day $^{-1}$ ) events, as determined by previous studies [40,41], are also presented.

\subsubsection{Severely Eroding Bank Lengths and Areas}

The length and height for every severely eroding stream bank in each reach or subreach were measured in all studies except Study 10 (Table 1). The percentage of total severely eroding bank length for each reach or subreach was calculated by dividing the total length of its severely eroding banks by its total stream bank length [57]. The total bank eroding area for each reach or subreach was determined as the sum of all its severely eroding bank areas divided by its total bank length.

\subsubsection{Annual Soil Loss}

Annual stream bank soil loss $\left(\mathrm{Mg}\right.$ year $\left.^{-1}\right)$ for each reach was estimated, for every year of each study that had bank erosion rates, with Equation (1): 


$$
S L=E A \times E R \times B D,
$$

where

$S L=$ soil loss $\left(\mathrm{Mg}\right.$ year $\left.^{-1}\right)$ by stream bank erosion,

$E A=$ stream bank eroding area $\left(\mathrm{m}^{2}\right)$,

$E R=$ stream bank erosion rate $\left(\mathrm{m}^{2}\right.$ year $\left.{ }^{-1}\right)$, and

$B D=$ stream bank soil bulk density $\left(\mathrm{Mg} \mathrm{m}^{-3}\right)$.

To be able to compare soil loss among subreaches or reaches of different riparian land-uses, soil loss was divided by its total stream length $\left(\mathrm{Mg} \mathrm{km}^{-1}\right.$ year $\left.^{-1}\right)$.

\subsubsection{Stocking Rate, Stream Order, Bank Aspect, Bank Position, and Rainfall and Stream Flow Data}

In Study 5 (Table 1), stream bank erosion rates were correlated with stream orders [39], since a range of stream orders were monitored, and stocking rates. The impact of aspect (north and south) and position (top and bottom bank) of stream bank rates and processes were investigated in Study 2 (Table 1).

\subsubsection{Stream Bank Erosion Processes}

To better understand stream bank erosion, rates and soil loss were correlated to rainfall and stream flows (Studies 1, 3 and 5; Table 1). Rainfall data were from the closest weather station, which was typically from the National Oceanic and Atmospheric Administration, while the streamflows were from the closest USGS gauging station. In addition, in Study 2, insights on how riparian land-uses impact major erosion processes were investigated (Study 2; Table 1). Fluvial entrainment, mass wasting or failure, and subaerial preparation (desiccation and freeze and thaw loosens the stream bank soil) are the three major natural stream bank erosion processes [60-62]. Since this study was conducted on second (2nd)-order streams (a headwater reach), subaerial processes were expected to be the dominant process [61].

\subsubsection{Gullies, Cattle Stream Access Points, and Cattle Loafing Areas}

Every classic and ephemeral gully and cattle stream access point of the reaches of Studies 6, 7, and 8 (Table 1) was counted [48]. Classic gullies have channels with depths ranging from 0.5 to $30 \mathrm{~m}$, while ephemeral gullies are defined as much shallower channels that tillage can erase [63]. The areas of the severely eroding banks of the ephemeral gullies were estimated by multiplying the entire length of the gully by its average depth. For classic gullies, the area of every severely eroding bank was estimated in the same way severely eroding stream banks were estimated.

In Study 9 (Table 1), in classic gullies that ended in reaches along a CP, RP, and IP (one in each), three pin plots were established. Severely eroding bank lengths and areas were measured, and yearly bank erosion rates and gully soil losses were estimated.

In Study 10 (Table 1), a survey was conducted to quantify the total areas of the cattle stream access points and cattle loafing areas within $15 \mathrm{~m}$ strips on both sides of the stream reaches [50]. Three pasture reaches with different stocking densities were selected in each region. Livestock access points and cattle loafing areas were classified by their stocking rates per hectare and per stream length (cow-day $\mathrm{ha}^{-1} \mathrm{~m}^{-1}$ year ${ }^{-1}$ ) [51]. Simulated rainfall plots were applied to three cattle stream access points, two control areas, and one cattle loafing area in each stream reach to quantify the contribution of total suspended sediment (TSS) to the streams originating from surface runoff [51]. The TSS load from each stream reach was calculated as the product of the total source area $\left(\mathrm{m}^{2}\right)$ for each source type (loafing, access, and control) and the TSS from the plots for each source area. 


\subsubsection{Stream Bed Substrate}

Percentages of the different stream bed substrates were estimated with a survey of 20 transects, spaced two mean stream widths apart, that was conducted from all reaches of Studies 6, 7, and 8 (Table 1) [46]. The visual protocol used to estimate substrate percentages was developed specifically for the state of Iowa by Heitke [64].

\subsubsection{Stream Water Total Suspended Sediment}

Stream water grab samples were collected during base flow conditions from the reaches of Studies 6, 7, and 8 (Table 1) [47]. Samples were analyzed for TSS based on the APHA (American Public Health Association) [65] standard method. For Study 3 (Table 1), daily TSS concentrations and loads used were obtained from the USGS and the USDA.

\subsubsection{Statistical Analysis}

An ANOVA (mixed model) and Student's t-tests (significant differences, $p<0.1$ ) were performed to compare gully and stream bank variables as well as substrate and TSS differences, respectively, among the riparian land-uses. In Study 10 (Table 1), a split-plot analysis with source areas and treatments (9 different stocking densities) was used to compare to the TSS contributions. Soil density and antecedent soil were used as covariates.

\section{Results}

\subsection{Stream Bank Annual Erosion Rates}

Stream bank erosion rates of the conservation practices were significantly less in most cases compared to the agricultural practices (see Table 2). Specifically, RF banks had lower erosion rates than the RC banks in Study 1 (in 1999 and 2000) and Study 7 (in 2003, 2004, 2002-2004). When compared to grazing practices, RF had lower bank erosion rates than the CP in Study 1 (in 1999), Study 6 (in 2003, 2004, 2002-2004), Study 7 (in 2004, 2002-2004), and the IP Study 6 (in 2004, 2002-2004). Only in Study 3 (in 2007-2008) did the RF banks have higher erosion rates than the CP banks. GF bank erosion rates were significantly less than CP in Study 2 (in 2004) and RC in Study 7 (in 2003, 2004). GF banks also had lower erosion rates than the grazed pasture banks in all periods in Study 5. Comparing conservation practices, the RF banks had higher erosion rates than both GF banks (in 2007-2008, 2009, 2005-2011) in Study 3. Finally, in some cases, while bank erosion rate differences between conservation (e.g., had deposition) and agricultural practices were large differences (see Studies 2 and 6), they were not significant because of the high erosion variability among pins (pins even within plots could have deposition and erosion for the same period). 
Table 2. The yearly stream and gully bank erosion rates $(\mathrm{mm})$ adjacent to different riparian land-uses from the different studies conducted in Iowa. The different letters in parenthesis indicate statistically significant differences $(p<0.1)$ among the different riparian land-uses.

\begin{tabular}{|c|c|c|c|c|c|c|c|c|c|}
\hline $\begin{array}{l}\text { Case Study } \\
\text { (Reference) }\end{array}$ & Erosion Type & Year & $\begin{array}{c}\text { Riparian Forest } \\
\text { Buffer (RF) }\end{array}$ & $\begin{array}{l}\text { Grass Filter } \\
\text { (GF) }\end{array}$ & $\begin{array}{c}\text { Fenced } \\
\text { Pasture (FP) }\end{array}$ & $\begin{array}{c}\text { Intensive Rot. } \\
\text { Pasture (IP) }\end{array}$ & $\begin{array}{c}\text { Rotational } \\
\text { Pasture (RP) }\end{array}$ & $\begin{array}{l}\text { Continuous } \\
\text { Pasture (CP) }\end{array}$ & $\begin{array}{l}\text { Row-Crop } \\
\text { Field (RC) }\end{array}$ \\
\hline & & & & & & $\mathrm{mm}_{\text {year }}{ }^{-1}$ & & & \\
\hline \multirow{5}{*}{$1[40,41]$} & \multirow{5}{*}{ Stream bank } & 1999 & 129 (b) & - & - & - & - & 304 (b) & 351 (a) \\
\hline & & 2000 & 4 (b) & - & - & - & - & $29(a b)$ & 119 (a) \\
\hline & & 2001 & 45 (a) & - & - & - & - & 165 (a) & 143 (a) \\
\hline & & 2002 & 37 (a) & - & - & - & - & 103 (a) & 50 (a) \\
\hline & & $1998-2002$ * & $50(\mathrm{~b})$ & - & - & - & - & 149 (a) & 161 (a) \\
\hline \multirow{3}{*}{$2[42]$} & \multirow{3}{*}{ Stream bank } & 2003 & $30(a)$ & - & - & - & - & 403 (a) & - \\
\hline & & 2004 & $80(a b)$ & $-4(b)$ & - & - & - & 130 (a) & - \\
\hline & & $2002-2004$ * & 55 (a) & - & - & - & - & 266 (a) & - \\
\hline \multirow{7}{*}{$3[25,43]$} & \multirow{7}{*}{ Stream bank } & 2005 & 3 (a) & 11 (a) & - & - & - & $-3(a)$ & - \\
\hline & & 2006 & 11 (a) & 22 (a) & - & - & - & -11 (a) & - \\
\hline & & $2007-2008$ * & 236 (a) & 209 (b) & - & - & - & 139 (b) & - \\
\hline & & 2009 & 401 (a) & 277 (b) & - & - & - & $305(\mathrm{ab})$ & - \\
\hline & & 2010 & 272 (a) & 192 (a) & - & - & - & 238 (a) & - \\
\hline & & 2011 & 140 (a) & 42 (a) & - & - & - & 164 (a) & - \\
\hline & & $2005-2011$ * & 172 (a) & $124(\mathrm{~b})$ & - & - & - & $139(\mathrm{ab})$ & - \\
\hline \multirow{4}{*}{$5[44,45]$} & \multirow{4}{*}{ Stream bank } & 2007 & - & 89 (a) & - & - & - & 152 (b) & - \\
\hline & & 2008 & - & 146 (b) & - & - & - & 261 (a) & - \\
\hline & & 2009 & - & 130 (a) & - & - & - & 294 (b) & - \\
\hline & & $2007-2009$ * & - & $121(\mathrm{~b})$ & - & - & - & 236 (a) & - \\
\hline \multirow{4}{*}{$6[49]$} & \multirow{4}{*}{ Stream bank } & 2002 & $-10(a b)$ & - & $-25(b)$ & $114(\mathrm{ab})$ & - & 151 (a) & - \\
\hline & & 2003 & $36(\mathrm{~b})$ & - & $54(\mathrm{ab})$ & $98(a b)$ & - & 184 (a) & - \\
\hline & & 2004 & 1 (c) & - & $24(\mathrm{c})$ & 313 (a) & - & 137 (b) & - \\
\hline & & $2002-2004$ * & $15(\mathrm{~b})$ & - & $22(\mathrm{~b})$ & 170 (a) & - & 171 (a) & - \\
\hline \multirow{4}{*}{$7[49]$} & \multirow{4}{*}{ Stream bank } & 2002 & 54 (a) & 87 (a) & - & - & 70 (a) & 79 (a) & 225 (a) \\
\hline & & 2003 & 4 (b) & $66(\mathrm{~b})$ & - & - & $54(\mathrm{~b})$ & $128(\mathrm{ab})$ & 223 (a) \\
\hline & & 2004 & $83(\mathrm{c})$ & 168 (c) & - & - & $198(\mathrm{bc})$ & 298 (a) & $271(\mathrm{ab})$ \\
\hline & & $2002-2004$ * & $46(\mathrm{c})$ & $106(\mathrm{bc})$ & - & - & $104(\mathrm{bc})$ & $166(a b)$ & 239 (a) \\
\hline \multirow{4}{*}{$8[49]$} & \multirow{4}{*}{ Stream bank } & 2002 & - & 37 (a) & 42 (a) & 59 (a) & 166 (a) & 127 (a) & - \\
\hline & & 2003 & - & 12 (a) & -6 (a) & 55 (a) & 16 (a) & 23 (a) & - \\
\hline & & 2004 & - & 109 (a) & 65 (a) & 169 (a) & 199 (a) & 182 (a) & - \\
\hline & & $2002-2004$ & - & 41 (a) & 58 (a) & 94 (a) & 122 (a) & 101 (a) & - \\
\hline \multirow{2}{*}{$9[50]$} & Gully & 2004 & - & - & - & $121(b)$ & $135(a b)$ & 245 (a) & - \\
\hline & Stream bank & 2004 & - & - & - & -143 (a) & 78 (a) & 157 (a) & - \\
\hline
\end{tabular}

* Average of years. 
From the grazing practices, FP showed the most promise. Specifically, in Study 6 the FP had lower bank erosion rates than CP (in 2002, 2004, 2002-2004) and the IP (in 2004, 2002-2004). In this study (in 2004), IP had higher bank erosion rates than CP. CP had higher bank erosion rates than RP (in 2004) but less than RC (in 2002-2004) in Study 7. Finally, in Study 5, there were no correlations between the pasture stocking rates and stream bank erosion rates.

Overall, more bank erosion differences might not have been observed because the pins and PEEPs were placed on severely eroding banks. It is also important to note that differences in bank erosion rates, even among the same land-uses, were observed from year to year, showing the high temporal variability of stream bank erosion.

\subsection{Stream Bank Erosion and Deposition Events}

The RF PEEPs in Study 2 recorded the most bank erosion (41 events in 2003; 57 events in 2004) and deposition events (30 events in 2003; 64 events in 2004). CP reaches had more bank events in 2003 (erosion 36; deposition 35) than in 2004 (erosion 28; deposition 31). GF banks, despite their very low erosion rates, still had 38 erosion (15) and deposition (23) events. Overall, CP banks had the highest annual bank erosion rates and the largest number of major bank erosion events. RF banks had the largest number of major bank deposition events, and GF banks had no major events.

\subsection{Severely Eroding Stram Bank Lengths and Areas}

RF reaches had significantly less severely eroded bank lengths and/or areas than RC (Studies 1, 4, 7), CP (Studies 1, 2, 6), and IP (Study 6) (Table 3). GF reaches had significantly less severely eroded bank lengths and/or areas than CP (Studies 2, 5, 8), RP (Study 8), IP (Study 8), and RC (Study 7) reaches (Table 3). Comparing the conservation practices, RF reaches had severely eroding bank lengths that were significantly different from GF (Study 3; Table 3).

FP reaches had significantly smaller severely eroding bank lengths and/or areas than CP (Studies 6, 8), RP (Study 8), and IP (Study 6). IP had significantly smaller severely eroding bank lengths and/or areas than $\mathrm{CP}$ and $\mathrm{RP}$ (Study 8). Severely eroding bank lengths and/or areas of the RR were significantly smaller than those of RC banks in Study 7. In Study 9, IP had severely eroding bank lengths that were significantly larger than those of RP and CP reaches. In contrast, severely eroding areas of the IP had the smallest severely eroding bank areas and RP had the largest. Finally, in Study 5, cattle stocking rates were significantly and positively correlated to the percentage of the eroded bank lengths along these reaches $\left(R^{2}=0.24, p=0.09\right)$.

\subsection{Annual Stream Bank Soil Loss}

Soil losses of the conservation practices were substantially less than the agricultural riparian land-uses (Table 4). Annual soil losses from RF banks ranged from having deposition $\left(-3 \mathrm{Mg} \mathrm{km}^{-1}\right.$ year $^{-1}$ ) to $52 \mathrm{Mg} \mathrm{km}^{-1}$ year $^{-1}$ and for the GF bank also from having deposition $\left(-2 \mathrm{Mg} \mathrm{km}^{-1}\right.$ year $^{-1}$ ) to $86 \mathrm{Mg} \mathrm{km}^{-1}$ year $^{-1}$. For grazing practices, annual soil losses ranged for FP banks from -7 to $68 \mathrm{Mg} \mathrm{km}^{-1}$ year $^{-1}$, for IP from 37 to $282 \mathrm{Mg} \mathrm{km}^{-1}$ year $^{-1}$, for RP from 35 to $434 \mathrm{Mg} \mathrm{km}^{-1}$ year $^{-1}$, and for $\mathrm{CP}$ from 27 to $473 \mathrm{Mg} \mathrm{km}^{-1}$ year ${ }^{-1}$. In Study 5, multiple regression analysis found that cattle stocking rates were not correlated to soil losses from stream banks. Finally, for RC banks, annual soil losses ranged from 29 to $345 \mathrm{Mg} \mathrm{km}^{-1}$ year ${ }^{-1}$. 
Table 3. Stream and gully severely eroding bank lengths (\%) and areas per stream length $\left(\mathrm{m}^{2} \mathrm{~km}^{-1}\right)$ adjacent to different riparian land-uses from different studies conducted in Iowa. This percentage is estimated by dividing the severely eroding bank length by the total length. The different letters in parenthesis indicate significant differences $(p<0.1)$ among the different riparian land-uses.

\begin{tabular}{|c|c|c|c|c|c|c|c|c|c|}
\hline $\begin{array}{l}\text { Case Study } \\
\text { (Reference) }\end{array}$ & Erosion Type & Year & $\begin{array}{c}\text { Riparian Forest } \\
\text { Buffer (RF) }\end{array}$ & $\begin{array}{l}\text { Grass Filter } \\
\text { (GF) }\end{array}$ & $\begin{array}{c}\text { Fenced } \\
\text { Pasture (FP) }\end{array}$ & $\begin{array}{l}\text { Intensive Rot. } \\
\text { Pasture (IP) }\end{array}$ & $\begin{array}{c}\text { Rotational } \\
\text { Pasture (RP) }\end{array}$ & $\begin{array}{l}\text { Continuous } \\
\text { Pasture (CP) }\end{array}$ & $\begin{array}{l}\text { Row-Crop } \\
\text { Field (RC) }\end{array}$ \\
\hline & & & & & & $\% / \mathrm{m}^{2} \mathrm{~km}^{-1}$ & & & \\
\hline \multirow{2}{*}{$1[40,41]$} & \multirow{2}{*}{ Stream bank } & 1998 & 27 (a)/372 & - & - & - & - & $42(b) / 592$ & $44(\mathrm{~b}) / 639$ \\
\hline & & 2002 & $14(\mathrm{a}) / 149$ & - & - & - & - & $41(\mathrm{~b}) / 578$ & 39 (b)/511 \\
\hline $2[42]$ & Stream bank & 2002 & $12(\mathrm{a}) / 120$ & $35(b) / 460$ & - & - & - & $54(\mathrm{c}) / 810$ & - \\
\hline $3[25,43]$ & Stream bank & 2004 & 27 (a) & $7(b)$ & - & - & - & $26(a b)$ & $19(\mathrm{ab})$ \\
\hline $4[43]$ & Stream bank & 2004 & 7 (b) & - & - & - & - & - & 13 (a) \\
\hline $5[44,45]$ & Stream bank & 2006 & - & 18 (a)/471 & - & - & - & $24(\mathrm{a}) / 786$ & - \\
\hline \multirow{2}{*}{$6[48,49]$} & Stream bank & 2004 & $10(\mathrm{~b}) / 305$ & - & $11(b) / 254$ & 27 (a)/750 & - & 38 (a)/1209 & - \\
\hline & Gully & 2004 & $0(\mathrm{a}) / 0$ & - & $0(\mathrm{a}) / 0$ & $67(\mathrm{a}) / 2$ & - & $10(\mathrm{a}) / 38$ & - \\
\hline \multirow{2}{*}{$7[48,49]$} & Stream bank & 2004 & $14(\mathrm{bc}) / 307$ & $16(\mathrm{bc}) / 384$ & - & - & $25(\mathrm{~b}) / 692$ & $39(\mathrm{ab}) / 1176$ & 44 (a)/1036 \\
\hline & Gully & 2004 & $76(\mathrm{a}) / 14$ & $43(\mathrm{a}) / 14$ & - & - & $51(\mathrm{a}) / 51$ & 44 (a) 56 & $74(\mathrm{a}) / 130$ \\
\hline \multirow{2}{*}{$8[48,49]$} & Stream bank & 2004 & - & 16 (c)/413 & $16(\mathrm{bc}) / 797$ & 32 (b)/530 & $54(\mathrm{a}) / 1602$ & $54(\mathrm{a}) / 1478$ & - \\
\hline & Gully & 2004 & - & $1(b) / 7$ & $54(\mathrm{a}) / 93$ & $33(\mathrm{ab}) / 125$ & $34(\mathrm{ab}) / 286$ & 49 (a)/147 & - \\
\hline \multirow{2}{*}{$9[50]$} & Gully & 2004 & - & - & - & 27 (c)/179 & $40(\mathrm{~b}) / 364$ & 47 (a)/304 & - \\
\hline & Stream bank & 2004 & - & - & - & 65 (a)/748 & $43(b) / 1080$ & 45 (b)/1550 & - \\
\hline
\end{tabular}


Table 4. The stream bank soil losses per stream length $\left(\mathrm{Mg} \mathrm{km}^{-1}\right.$ year $\left.{ }^{-1}\right)$ and gully bank soil losses per gully length $\left(\mathrm{Mg} \mathrm{km}^{-1}\right.$ year $\left.{ }^{-1}\right)$ of different riparian land-uses from different case-studies conducted in Iowa.

\begin{tabular}{|c|c|c|c|c|c|c|c|c|c|}
\hline $\begin{array}{l}\text { Case Study } \\
\text { (Reference) }\end{array}$ & Erosion & Year & $\begin{array}{c}\text { Riparian Forest } \\
\text { Buffer (RF) }\end{array}$ & $\begin{array}{l}\text { Grass Filter } \\
\text { (GF) }\end{array}$ & $\begin{array}{c}\text { Fenced } \\
\text { Pasture (FP) }\end{array}$ & $\begin{array}{l}\text { Intensive Rot. } \\
\text { Pasture (IP) }\end{array}$ & $\begin{array}{c}\text { Rotational } \\
\text { Pasture (RP) }\end{array}$ & $\begin{array}{l}\text { Continuous } \\
\text { Pasture (CP) }\end{array}$ & $\begin{array}{l}\text { Row-Crop } \\
\text { Field (RC) }\end{array}$ \\
\hline \multirow{5}{*}{$1[40,41]$} & \multirow{5}{*}{ Stream bank } & 1999 & 52 & - & - & - & - & 281 & 266 \\
\hline & & 2000 & 8 & - & - & - & - & 100 & 29 \\
\hline & & 2001 & 2 & - & - & - & - & 76 & 164 \\
\hline & & 2002 & 6 & - & - & - & - & 27 & 98 \\
\hline & & 1998-2002 & 19 & - & - & - & - & 121 & 139 \\
\hline \multirow{3}{*}{$2[42]$} & \multirow{3}{*}{ Stream bank } & 2003 & 4 & - & - & - & - & 437 & - \\
\hline & & 2004 & 12 & -2 & - & - & - & 141 & - \\
\hline & & 2002-2004 & 8 & - & - & - & - & 289 & - \\
\hline \multirow{4}{*}{$5[44,45]$} & \multirow{4}{*}{ Stream bank } & 2007 & - & 51 & - & - & - & 191 & - \\
\hline & & 2008 & - & 86 & - & - & - & 310 & - \\
\hline & & 2009 & - & 77 & - & - & - & 348 & - \\
\hline & & 2007-2009 & - & 71 & - & - & - & 283 & - \\
\hline \multirow{4}{*}{6 [49] } & \multirow{4}{*}{ Stream bank } & 2002 & -3 & - & -7 & 103 & - & 210 & - \\
\hline & & 2003 & 12 & - & 16 & 88 & - & 256 & - \\
\hline & & 2004 & 0 & - & 7 & 282 & - & 191 & - \\
\hline & & 2002-2004 & 5 & - & 6 & 153 & - & 238 & - \\
\hline \multirow{4}{*}{$7[49]$} & \multirow{4}{*}{ Stream bank } & 2002 & 21 & 39 & - & - & 63 & 125 & 287 \\
\hline & & 2003 & 2 & 29 & - & - & 49 & 203 & 284 \\
\hline & & 2004 & 32 & 75 & - & - & 179 & 473 & 345 \\
\hline & & 2002-2004 & 18 & 47 & - & - & 94 & 264 & 304 \\
\hline \multirow{4}{*}{8 [49] } & \multirow{4}{*}{ Stream bank } & 2002 & - & 20 & 44 & 40 & 362 & 248 & - \\
\hline & & 2003 & - & 6 & -6 & 37 & 35 & 45 & - \\
\hline & & 2004 & - & 58 & 68 & 115 & 434 & 355 & - \\
\hline & & 2002-2004 & - & 22 & 61 & 64 & 266 & 197 & - \\
\hline \multirow{2}{*}{$9[50]$} & Gully & 2004 & - & - & - & 28 & 89 & 207 & - \\
\hline & Stream bank & 2004 & - & - & - & 170 & 282 & 323 & - \\
\hline
\end{tabular}




\subsection{Precipitation and Stream Flows}

In Study 1, bank erosion rates of all riparian land-uses in 1999 were significantly greater than those in 2000, 2001, and 2002, and in Study 3 in 2009-2011 they were significantly greater than those in 2005-2006. Severely eroding bank lengths and areas in Study 1 also decreased from 1998 to 2002 in all riparian land-uses. This corresponds well with precipitation amounts of the study period that were above the annual average in the years with greater stream bank erosion rates, lengths, and areas. In contrast, in Studies 2 and 5, bank erosion rates did not follow the yearly precipitation. In Study 5 this was because of the high bank erosion rates in the winter/spring seasons, indicating other process causing stream bank erosion. This was also indicative of the multiple regression analysis between precipitation and stream bank erosion rates in Study 5 that found a significant, positive relationship in 2007 but negative relationships in 2008 and 2009. In Study 3, maximum daily stream flow was significantly correlated to stream bank erosion rates and soil loss, especially in 2009. The two major stream flow events in 2007, on 25 April $\left(11 \mathrm{~m}^{3} \mathrm{~s}^{-1}\right)$ and on 7 May $\left(5 \mathrm{~m}^{3} \mathrm{~s}^{-1}\right)$ represented $37 \%$ of total annual sediments exported from the watershed. In addition, the increase by $22 \%$ of the eroding bank length from 2004 to 2010 was the result of the increased number of larger stream flow events. Similarly, in Study 5, a significant correlation $\left(\mathrm{R}^{2}=75\right)$ was found, with high bank erosion prevalent during bankfull or greater stream flows.

\subsection{Stream Order, Bank Aspect, and Position}

In Study 5 along grazed pastures, the third-order reaches had significantly higher bank erosion rates and soil losses ( $380 \mathrm{~mm}$; $638 \mathrm{Mg} \mathrm{km}^{-1}$ year $^{-1}$ ) than both the second- $\left(157 \mathrm{~mm} ; 187 \mathrm{Mg} \mathrm{km}^{-1}\right.$ year $^{-1}$ ) and first-order reaches (200 mm; $177 \mathrm{Mg} \mathrm{km}^{-1}$ year $^{-1}$ ). In Study 2, in 2003 and 2004, the north top-bank (1070 and $235 \mathrm{~mm}_{\text {year }}{ }^{-1}$, respectively) of the CP had more erosion than the bottom-bank (265 and $125 \mathrm{~mm}$, respectively) while the south top-bank ( 45 and $50 \mathrm{~mm} \mathrm{year}^{-1}$, respectively) had less erosion than the bottom-bank (230 and $100 \mathrm{~mm}^{\text {year }}{ }^{-1}$, respectively). In the RF in 2003, the north and south top-bank had more erosion ( 65 and $30 \mathrm{~mm}$ year $^{-1}$, respectively) than the bottom-bank ( 5 and $20 \mathrm{~mm} \mathrm{year}^{-1}$, respectively). In 2004, the north top-bank had erosion $\left(35 \mathrm{~mm}_{\text {year }}{ }^{-1}\right)$ and the bottom-bank deposition $\left(-60 \mathrm{~mm}\right.$ year $\left.^{-1}\right)$ while the south top-bank had less erosion (110 mm year ${ }^{-1}$ ) than the bottom-bank (230 mm year $\left.{ }^{-1}\right)$. GF banks had the lowest erosion rates on the north and south top-bank (20 and $40 \mathrm{~mm} \mathrm{year}^{-1}$, respectively) and deposition on the north and south bottom-bank ( -35 and $-40 \mathrm{~mm}_{\text {year }}{ }^{-1}$, respectively).

\subsection{Stream Erosion and Deposition Processes}

In Study 1, bank erosion rates $>20 \mathrm{~mm}$ per event were measured in spring and early summer and characterized by many medium (20-40 $\left.\mathrm{mm}^{-1 a y}{ }^{-1}\right)$ and/or large $\left(>40 \mathrm{~mm} \mathrm{day}^{-1}\right)$ daily precipitation events. In the fall, high bank erosion rates $>20 \mathrm{~mm}$ per event occurred with low $\left(<20 \mathrm{~mm} \mathrm{day}^{-1}\right)$ daily precipitation events, indicating that other processes were causing bank erosion. In Studies 3 and 5, flashy stream flows, typical of streams in Iowa, caused erosion by direct fluvial entrainment during these high flows or by mass wasting as the stream flow receded and no longer supported the steep banks. Dominant processes were more accurately assessed in Study 2 because of the higher temporal resolution of the measurements. $\mathrm{CP}$ banks had high erosion rates during the spring and early summer months with fluvial entrainment being the dominant process, although minor mass failures also occurred. Major depositional events also occurred from March to June with cattle trampling being the probable cause. In contrast, RF banks were susceptible to fluvial entrainment by moderate stream flows that occurred in early spring and were aided by freeze-thaw cycling events. Major deposition events in the RF were caused by desiccation (August-September) and by freeze-thaw cycling (November and winter). Finally, in some cases the bank erosion process could not be determined.

\subsection{Gullies, Cattle Access Points, and Loafing Areas}

In Studies 6, 7, and 8, few significant differences were found among riparian land-uses for the gully variables (Table 5). RC had primarily ephemeral gullies $\left(3.8 \mathrm{~km}^{-1}\right)$ while classic gullies were dominant in the other riparian land-uses. 
Table 5. The number of gullies (both classic and ephemeral) and cattle access points and the severely eroding gully bank areas per stream length in the NE, CE, and SE region studies. Significant differences among riparian land-uses within a region are indicated with a different letter in parenthesis $(p<0.1)$

\begin{tabular}{|c|c|c|c|c|c|c|c|c|}
\hline $\begin{array}{l}\text { Case Study } \\
\text { (Reference) }\end{array}$ & $\begin{array}{l}\text { Gully and Cattle Access } \\
\text { Variable }\end{array}$ & $\begin{array}{l}\text { Riparian Forest } \\
\text { Buffer (RF) }\end{array}$ & $\begin{array}{l}\text { Grass Filter } \\
\quad \text { (GF) }\end{array}$ & $\begin{array}{l}\text { Fenced Pasture } \\
\text { (FP) }\end{array}$ & $\begin{array}{l}\text { Intensive Rot. } \\
\text { Pasture (IP) }\end{array}$ & $\begin{array}{l}\text { Rotational } \\
\text { Pasture (RP) }\end{array}$ & $\begin{array}{l}\text { Continuous } \\
\text { Pasture (CP) }\end{array}$ & $\begin{array}{l}\text { Row-Crop } \\
\text { Field (RC) }\end{array}$ \\
\hline \multirow{3}{*}{$6[48]$} & $\begin{array}{l}\text { Gullies per unit stream length } \\
\qquad\left(\# \mathrm{~km}^{-1}\right)\end{array}$ & $1.5(b)$ & - & 1.5 (a) & 3.0 (a) & - & 1.3 (a) & - \\
\hline & $\begin{array}{l}\text { Cattle access points per unit } \\
\text { stream length }\left(\# \mathrm{~km}^{-1}\right)\end{array}$ & NA (-) * & - & NA (-) & $75(b)$ & - & 149 (a) & - \\
\hline & $\begin{array}{l}\text { Severely eroding gully bank } \\
\text { areas per unit stream length } \\
\qquad\left(\mathrm{m}^{2} \mathrm{~km}^{-1}\right)\end{array}$ & 0 (a) & - & 0 (a) & 38 (a) & - & $2(\mathrm{a})$ & - \\
\hline \multirow{3}{*}{$7[48]$} & $\begin{array}{l}\text { Gullies per unit stream length } \\
\left(\# \mathrm{~km}^{-1}\right)\end{array}$ & $1.5(b)$ & $3.0(\mathrm{ab})$ & - & - & $3.5(a b)$ & $3.5(\mathrm{ab})$ & 7 (a) \\
\hline & $\begin{array}{l}\text { Cattle access points per unit } \\
\text { stream length }\left(\# \mathrm{~km}^{-1}\right)\end{array}$ & NA (-) & NA (-) & - & - & 66 (a) & 84 (a) & NA (-) \\
\hline & $\begin{array}{l}\text { Severely eroding gully bank } \\
\text { areas per unit stream length } \\
\qquad\left(\mathrm{m}^{2} \mathrm{~km}^{-1}\right)\end{array}$ & 14 (a) & 14 (a) & - & - & 51 (a) & 56 (a) & 130 (a) \\
\hline \multirow{3}{*}{$8[48]$} & $\begin{array}{l}\text { Gullies per unit stream length } \\
\left(\# \mathrm{~km}^{-1}\right)\end{array}$ & - & $5.0(\mathrm{a})$ & 3.0 (a) & $8.0(a)$ & $6.5(\mathrm{a})$ & 4.3 (a) & - \\
\hline & $\begin{array}{l}\text { Cattle access points per unit } \\
\text { stream length }\left(\# \mathrm{~km}^{-1}\right)\end{array}$ & - & NA (-) & NA (-) & $101(\mathrm{a})$ & 54 (a) & 139 (a) & - \\
\hline & $\begin{array}{l}\text { Severely eroding gully bank } \\
\text { areas per unit stream length } \\
\qquad\left(\mathrm{m}^{2} \mathrm{~km}^{-1}\right)\end{array}$ & - & 7 (b) & $93(a b)$ & $125(\mathrm{ab})$ & 286 (a) & $147(\mathrm{ab})$ & - \\
\hline
\end{tabular}

* NA not applicable. 
In Study 9, CP gullies had a significantly higher erosion rate and soil loss than those in the RP and IP (Tables 2 and 4). Within each grazing practice the gully erosion rates were significantly higher than the corresponding stream bank erosion rates (Table 2). In contrast, total soil losses from stream bank erosion were substantially larger than those from gully banks.

Within the $15 \mathrm{~m}$ strips along all of the pasture on both sides of the reaches in Study 10, cattle loafing, cattle access points, and control areas accounted for $1.2 \%, 1.5 \%$, and $97.3 \%$, respectively. This suggested that cattle used intensively $<3 \%$ the $15 \mathrm{~m}$ strips. The average surface runoff, TSS runoff concentrations, and average soil loss from the rainfall simulations were significantly higher from the cattle access points ( $11 \mathrm{~L}$ and $12.4 \mathrm{~g} \mathrm{~L}^{-1}$ and $236 \mathrm{~kg} \mathrm{~km}^{-1}$, respectively) than from both the cattle loafing ( $8 \mathrm{~L}$ and $5.2 \mathrm{~g} \mathrm{~L}^{-1}$ and $99 \mathrm{~kg} \mathrm{~km}^{-1}$, respectively) and control area plots (6 $\mathrm{L}$ and $0.5 \mathrm{~g} \mathrm{~L}^{-1}$ and $20 \mathrm{~kg} \mathrm{~km}^{-1}$, respectively). Average surface runoff, TSS runoff concentrations, and average soil loss from the loafing areas were also significantly higher than from the control areas. Finally, significantly positive correlations between stocking rates and soil losses were found for the control $\left(R^{2}=0.98\right)$ and for the loafing areas $\left(R^{2}=0.99\right)$ in the southeast region.

\subsection{Stream Bed Substrate}

The dominant substrates for all land-uses were fines (almost always $>50 \%$ ), in Studies 7 and 8 . In Study 6, the dominant substrate was sand $(>30 \%)$, except CP where fines dominated. Regarding CPOM, FP stream beds had a significantly higher percentage than IP (Study 6), RF and GF had significantly higher percentages than the agricultural land-uses (Study 7), and IP had a significantly higher percentage than RP (Study 8). The boulders of the stream beds of the RF had significantly higher percentages than RC and CP (Study 7), while FP was significantly sandier than the CP (Study 6). Finally, FP stream beds had a significantly higher percentage of gravel and lower percentage of fines than CP, RP, IP, and GF (Study 8).

\subsection{Stream Water Total Suspended Sediments}

TSS concentrations for all seasons were almost always less than $0.05 \mathrm{mg} \mathrm{L}^{-1}$ and rarely exceeded $0.1 \mathrm{mg} \mathrm{L}^{-1}$ (Studies 6,7 , and 8). Very few significant differences in TSS among the riparian land-uses were found and only in one season (not the same) out of the seven that water samples were collected. Specifically, in Study 7, reaches adjacent to RP had significantly lower TSS concentrations than GF, RC, and RF, and reaches adjacent to RF had significantly lower TSS concentrations than CP. In Studies 6 and 8 , reaches adjacent to $\mathrm{CP}$ had significantly higher TSS concentrations than all the other riparian land-uses.

In Study 3 the annual sediment loads exported differed greatly based on hydrologic conditions. The greatest sediment load was in 2011 with $25,815 \mathrm{Mg}$ year $^{-1}$ that was 4 times greater than the load in 2005. For 2005-2011 the average contributions from stream bank erosion was 33\% (ranging $1.5 \%-51 \%$ ), showing that a substantial amount of the sediment was exported from the watershed by stream bank erosion.

\section{Discussion}

Stream bank erosion rates for RF, GF, and FP in all reviewed studies, except Study 3, were below $130 \mathrm{~mm}$ year $^{-1}$ (Table 2). The larger erosion rates in Study 3 in RF were the result of the large number of wildlife present. RC, CP, RP, and IP reaches had erosion rates that were greater than $190 \mathrm{~mm}^{-1} \mathrm{yr}^{-1}$, while in many individual plots they were greater than $500 \mathrm{~mm}_{\text {year }}{ }^{-1}$, indicating substantial bank erosion. Annual bank erosion rates of individual pins were as much as three times higher than the average plot rate. Even on relatively 'stable' banks with steep slopes, small erosion and deposition events still occurred (Study 2), indicating that annual bank erosion rates are better related to major erosion and deposition bank events. Overall, more significant differences in bank erosion rates among the riparian land-uses were expected. Severely eroding bank lengths of RF, GF, and FP reaches, in most cases, were below 20\% (Studies 1-8; Table 3), which is typical of high-quality streams [66]. Severely eroding bank lengths in the RC were very high in central Iowa studies but substantially lower in the 
southeast (Studies 1, 3, 4, 8; Table 3). All three pasture systems (CP, RP, and IP) had severely eroding bank lengths that exceeded 20\%, while in some cases they even exceeded 50\% (Studies 1-3, 5-9; Table 3). Inventorying of severely eroding bank lengths found more significant differences among riparian land-uses than erosion rates. The survey should be the first assessment on stream bank erosion and take place before and some years after implementation of best management practices (e.g., RF, GF). Erosion pins or other methods (cross-section, PEEPs, etc.) are still necessary to determine erosion or deposition rates of the banks. In regard to soil losses, RF, GF, and FP had less than 90 tons km $\mathrm{km}^{-1} \mathrm{year}^{-1}$ (Table 4). In contrast, in IP, RP, CP, and RC, soil losses were 3-9 times higher than conservation practices and exceed 280 tons $\mathrm{km}^{-1}$ year ${ }^{-1}$ (Table 4 ).

Accelerated stream bank erosion rates in landscapes dominated by agriculture provides significant contributions to the stream sediment load $[3,17,67,68]$. In Study 5, the stream bank sediment load contribution from 2005-2011 averaged 33\%. The main reason was the removal of riparian trees and perennial vegetation. Stream banks along RC are highly susceptible to erosion because they are incised with reduced vegetation cover and have very shallow annual roots present for only part of the year $[62,69]$. In the Midwest, livestock are confined in riparian areas and spend a lot of time in the stream and along the banks, since streams are their only or main water source. Livestock trampling and treading can lead to mechanical breakdown of stream banks, thus increasing their susceptibility to erosion, and removal of the protective vegetation of the banks [70,71].

Re-establishment of perennial vegetation along stream banks, gullies, and riparian areas, especially in deeply incised channels in landscapes dominated by agriculture, is a simple, relatively inexpensive, and sustainable restoration technique to reduce erosion [72-76]. Based on these reviewed studies, these conservation efforts should prioritize streams because of their larger (6-484 times) severely eroding bank areas and greater sediment contributions ( $>75 \%$ ) than gullies (Studies 6, 7, 8; Table 3). Focus should be on third-order streams because of their taller and more susceptible to erosion banks and higher stream power of the water running through these reaches compared to first and second order (Study 5) [29]. Overall, by re-establishing conservation practices (RF and GF) along narrow riparian areas $(2 \%-3 \%$ of the agricultural land at the watershed scale) that are difficult to cultivate and frequently flood, stream bank erosion could be reduced by more than $75 \%$ (Table 4). Finally, Diebel et al. [77] found that by targeting areas that produce the highest $10 \%$ of sediment, watershed stream sediment loads can be reduced by $20 \%$.

Similar to past studies, this review had some studies that indicated trees (Study 7) [62,72,78] as better for bank stabilization while others indicated grasses (Studies 2 and 3) [79,80]. Perennial plant communities with vigorous root systems, regardless of whether they are trees or grasses, increase stream bank stability, especially in headwater streams [81] (Tables 2-4). It has been suggested in pastures that limiting and excluding cattle access from the stream channel and banks for certain periods, in order to re-establish perennial vegetation, stabilize banks [20]. In most of these reviewed studies (Tables 2-4), there were few indications that moving to RP and IP would stabilize banks, suggesting other factors might be more important. Study 5 suggests reducing stocking rates to improve stream bank stabilization. Overall, FP had greater stream bank stability than the other grazing systems where the cattle had full access to the stream (Tables 2-4), although it increased operational costs.

Annual stream bank erosion along reaches with the same riparian land-use had high temporal variation, indicating the importance of other variables (Table 2). In Studies 3 and 5, stream flow was significantly correlated to stream bank erosion rates and/or soil loss. In Study 3 in 2009, above average precipitation and stream flows led to bank erosion rates $\left(5479 \mathrm{~mm} \mathrm{year}^{-1}\right)$ and stream bank sediment contributions (51\%) significantly greater than those of 2005-2006 (143 mm year ${ }^{-1}$ and $1.5 \%$, respectively). This was not the case in Study 2. Stream bank erosion annual variability indicates the need for multiple-year datasets to accurately estimate long-term bank erosion contributions to stream sediment loads [82].

No clear patterns were evident for bank position (top and bottom) (Study 2). Overall, researchers have found contradicting results, since concave banks should have the top part of the banks more 
unstable with more frequent freeze-thaw cycling and soil desiccation (subaerial processes), but the bottom-banks should have more frequent exposure to stream flows $[62,67,83]$. South-banks during the summer have more desiccation events, while higher diurnal temperature variation during the winter leads to more freeze-thaw cycling and more friable bank material easily eroded by even moderate stream flows $[83,84]$. This was not evident in Study 2 in RF and GF banks, probably because trees and perennial grasses dampened sunlight effects [62], and in CP banks, because cattle impacts were more important for bank erosion than freeze-thaw cycling and desiccation.

Typically, subaerial processes dominate stream bank erosion in headwater streams ( $\leq 3 \mathrm{rd}$ order) [61, 85]. This was not the case in our reviewed studies where fluvial entrainment or mass wasting were the dominant processes along tall, vertical stream banks (Studies 3 and 5), which are indications of disturbed streams. Riparian land-uses also clearly influenced the timing and processes of major erosion and deposition events (Study 2). On CP banks, fluvial entrainment was the dominant bank erosion process, although minor mass failures also occurred. Major depositional events occurred primarily by cattle trampling and treading. The impact of a deep root system of perennial vegetation was evident in the RF reach (Study 2). Most erosion occurred by moderate stream flows (fluvial entrainment) in early spring, when trees provide only mechanical reinforcement, and not during the large stream flow events. These moderate stream flows were aided by freeze-thaw cycling events, but banks were also susceptible because of the high soil moisture [60] from the infiltrating water of the melting snowpack. Major deposition events in RF occurred also by desiccation. Finally, the process of a melting snowpack that can physically move down along the bank and cause erosion and deposition events needs to be further investigated.

Areas with no vegetation near the stream banks that can include gullies, cattle stream access points, and cattle loafing areas also contribute to stream sediment load [86]. Few differences were found between conservation practices and agricultural practices for the different gully variables (Studies 6, 7, and 8; Tables 2-5), probably because only the lower end segments of the gullies were subject to conservation practices, and well-developed gullies take a long time to restore [87]. In-field measures to mitigate gully erosion, such as: 1) narrow protection areas adjacent to the entire gully length and in the head-cuts; 2) bioengineering works on the gully beds, banks, and the head-cuts; and 3) grass waterways for ephemeral gullies, might also be required because well-established gullies are difficult to alleviate $[88,89]$.

Similar to other studies $[70,90,91]$, the great number of cattle stream access points (Table 5) in Studies 6, 7, and 8 show their potential as an important source of sediment to the streams in pastures where cattle have full access to the stream. In Study 5, re-introduction of wildlife in the Neil Smith Refuge had also led to many similar stream wildlife access points in RF [43], indicating that high wildlife populations can also cause bank erosion problems. Cattle stream access points and cattle loafing areas accounted for most of the soil losses (72\%) to streams from surface runoff, but it was only for $2.7 \%$ out of the total riparian area (Study 5). To mitigate sediment losses from stream access points and loafing areas, the cattle should be fenced at least five meters away from both sides of the stream banks along with armored and fenced stream crossings and drinking areas.

There were significant indications that conservation practices reduced stream bank erosion (Tables 3 and 4), and similar trends were expected in stream water quality and bed substrate [92,93]. The few significant differences in the stream bed substrate between conservation and agricultural reaches in these reviewed studies $(6,7$, and 8$)$, because of the high percentages of fines of most riparian land-uses, were the result of the embeddedness of the other bed substrates and the homogenization of the stream bed composition. This has also been found in other studies conducted in Iowa $[94,95]$ and is the result of soil loss from agricultural land-uses that indicates highly disturbed streams. Similarly, few significant differences were found in TSS among riparian land-uses (Studies 6, 7, and 8) because sampling was done during baseflow conditions. Other studies with established conservation riparian land-uses in agricultural watersheds have found reduced stream pollutant concentrations even during baseflow conditions $[96,97]$. 


\section{Conclusions}

Overgrazed pastures with full access to the stream channel and row-cropped fields up to the edge of the bank contribute significant amounts of nonpoint sediment to water bodies from stream bank and gully erosion. Stream bank erosion appears to be a greater source of sediment compared to gully erosion. Cattle loafing areas and cattle stream access points are also major sediment sources. Restricting agricultural activities from the riparian areas (e.g., RF and GF) or from the stream banks (e.g., FP) are effective and sustainable conservation practices in landscapes dominated by agriculture. Only a small portion (e.g., riparian area) of the watershed (about $2 \%-3 \%$ ) is taken out of production, but major sources of sediment (stream banks, gullies, cattle access points, and loafing areas) are significantly reduced.

The initial assessment method to determine land-use and conservation practice impacts on stream bank erosion should be to survey their severely eroding lengths and areas. Utilizing pins or cross-sections is still important because it allows estimating erosion rates and calculating bank soil loses. Long-term datasets are necessary to more accurately estimate rates of stream bank and gully erosion and soil loss because of the high temporal variation. Understanding of the timing and processes along with long-term datasets will allow land managers to implement the most appropriate conservation practices. This could be done by utilizing instrumentation that measures erosion continuously or semi-continuously such as PEEPs [58,59], thermal consonance timing [98], or the Automated Soil Erosion Monitoring System (ASEMS) [99].

The lack of stream bed substrate and water quality improvements in these studies from the conservation practices were probably because of upstream contributions and/or of the lingering effects of historical legacies of the past agricultural land-uses. As time passes, the vegetation of the conservation land-uses will further grow and will be better established, potentially alleviating these lingering effects and, thus, improving stream water quality and bed substrate. In addition, a holistic watershed approach that accounts for spatial and temporal soil erosion variability and targets and establishes conservation practices in the areas that produce most of the sediment should be developed to maximize the effectiveness of the conservation measures.

Author Contributions: For conceptualization, methodology, writing—original draft preparation, writing—review and editing, and formal analysis, G.N.Z., M.T., and R.C.S. were involved.

Funding: This research received no external funding.

Acknowledgments: The authors would like to thank the many undergraduate and graduate students, researchers, and professors that have been involved in numerous studies that the Agroforestry Team at Iowa State has conducted that have led to understanding of the important riparian areas' management.

Conflicts of Interest: The authors declare no conflict of interest.

\section{References}

1. Bernhardt, E.S.; Palmer, M.A.; Allan, J.D.; Alexander, G.; Barnas, K.; Brooks, S.; Carr, J.; Clayton, S.; Dahm, C.; Follstad-Shah, J.; et al. Synthesizing U.S. river restoration efforts. Science 2005, 308, 636-637. [CrossRef] [PubMed]

2. McCormick, A.; Fisher, K.; Brierley, G. Quantitative assessment of the relationships among ecological, morphological and aesthetic values in a river rehabilitation initiative. J. Environ. Manag. 2015, 153, 60-67. [CrossRef] [PubMed]

3. Fox, G.A.; Purvis, R.A.; Penn, C.J. Streambanks: A net source of sediment and phosphorus to streams and rivers. J. Environ. Manag. 2016, 181, 602-614. [CrossRef] [PubMed]

4. Salo, J.; Kalliola, R.; Hakkinen, I.; Makinen, Y.; Niemala, P.; Puhakka, M.; Coley, P.D. River dynamics and the diversity of the Amazon lowland forest. Nature 1986, 322, 254-258. [CrossRef]

5. Lane, S.N.; Tayefi, V.; Reid, S.C.; Yu, D.; Hardy, R.J. Interactions between sediment delivery, channel change, climate change and flood risk in a temperate upland environment. Earth Surf. Process. Landf. 2006, 32, 429-446. [CrossRef] 
6. Stover, S.C.; Montgomery, D.R. Channel change and flooding, Skokomish River, Washington. J. Hydrol. 2001, 243, 272-286. [CrossRef]

7. Pinter, N.; Heine, R.A. Hydrodynamic and morphodynamic response to river engineering documented by fixed-discharge analysis, Lower Missouri River, USA. J. Hydrol. 2005, 302, 70-91. [CrossRef]

8. Owens, P.N.; Batalla, R.J.; Collins, A.J.; Gomez, B.; Hicks, D.M.; Horowitz, A.J.; Kondolf, G.M.; Marden, M.; Page, M.J.; Peacock, D.H.; et al. Fine-grained sediment in river systems: Environmental significance and management issues. River Res. Appl. 2005, 21, 693-717. [CrossRef]

9. Kotak, B.G.; Prepas, E.E.; Hrudey, S.E. Blue green algal toxins in drinking water supplies: Research in Alberta. LakeLine 1994, 14, 37-40.

10. Martin, A.; Cooke, G.D. Health risks in eutrophic water supplies. LakeLine 1994, 14, $24-26$.

11. Newcombe, C.P.; Jensen, J.O.T. Channel suspended sediment and fisheries: A synthesis for quantitative assessment of risk and impact. N. Am. J. Fish. Manag. 1996, 16, 693-727. [CrossRef]

12. Pierzynski, G.M.; Sims, J.T.; Vance, G.F. Soils and Environmental Quality; CRC Press: Boca Raton, FL, USA, 2000.

13. Midgley, T.L.; Fox, G.A.; Derek, M.; Heeren, D.M. Evaluation of the bank stability and toe erosion model (BSTEM) for predicting lateral retreat on composite streambanks. Geomorphology 2012, 145-146, 107-144. [CrossRef]

14. Matono, P.; Batista, T.; Sampaio, E.; Ilheu, M. Effects of Agricultural Land Use on the Ecohydrology of SmallMedium Mediterranean River Basins: Insights from a Case Study in the South of Portugal. In Land Use. Assessing the Past, Envisioning the Future; Loures, L.C., Ed.; Intenchopen: London, UK, 2018; pp. 30-51.

15. Botero-Acosta, A.; Chua, M.L.; Guzman, J.A.; Starks, P.J.; Moriasi, D.N. Riparian erosion vulnerability model based on environmental features. J. Environ. Manag. 2017, 203, 592-602. [CrossRef] [PubMed]

16. Kelley, D.W.; Nater, E.A. Historical sediment flux from three watersheds into Lake Pepin, Minnesota, USA. J. Environ. Qual. 2000, 29, 561-568. [CrossRef]

17. Sekely, A.C.; Mulla, D.J.; Bauer, D.W. Streambank slumping and its contribution to the phosphorus and suspended sediment loads of the Blue Earth River, Minnesota. J. Soil Water Conserv. 2002, 57, 243-250.

18. Thoma, D.P.; Gupta, S.C.; Bauer, M.E.; Kirchoff, C.E. Airborne laser scanning for riverbank erosion assessment. Remote Sens. Environ. 2005, 95, 493-501. [CrossRef]

19. Kessler, A.C.; Gupta, S.C.; Dolliver, H.A.S.; Thoma, D.P. Lidar quantification of bank erosion in Blue Earth County, Minnesota. J. Environ. Qual. 2012, 41, 197-207. [CrossRef]

20. Lamba, J.; Thompson, A.M.; Karthikeyana, K.G.; Fitzpatrick, F.A. Sources of fine sediment stored in agricultural lowland streams, Midwest, USA. Geomorphology 2015, 236, 44-53. [CrossRef]

21. Hamlett, J.M.; Baker, J.L.; Johnson, H.P. Channel morphology changes and sediment yield for a small agricultural watershed in Iowa. Trans. ASAE 1983, 26, 1390-1396. [CrossRef]

22. Odgaard, A.J. Streambank erosion along two rivers in Iowa. Water Resour. Res. 1987, 23, $1225-1236$. [CrossRef]

23. Schilling, K.E.; Isenhart, T.M.; Palmer, J.A.; Wolter, C.F.; Spooner, J. Impacts of landcover change on suspended sediment transport in two agricultural watersheds. J. Am. Water Resour. Assoc. 2011, 47, 672-686. [CrossRef]

24. Schilling, K.E.; Wolter, C.F. Applications of GPS and GIS to map channel features in Walnut Creek, Iowa. J. Am. Water Resour. Assoc. 2000, 36, 1423-1434. [CrossRef]

25. Palmer, J.A.; Schilling, K.E.; Isenhart, T.M.; Schultz, R.C.; Tomer, M.D. Streambank erosion rates and loads within a single watershed: Bridging the gap between temporal and spatial scales. Geomorphology 2014, 209, 66-78. [CrossRef]

26. Fitzpatrick, F.A.; Knox, J.C.; Schubauer-Berigan, J.P. Channel, floodplain, and wetland responses to floods and overbank sedimentation, 1846-2006, Halfway Creek Marsh, Upper Mississippi Valley, Wisconsin. In Management and Restoration of Fluvial Systems with Broad Historical Changes and Human Impacts; James, L.A., Rathburn, S.L., Whittecar, G.R., Eds.; Geological Society of America: Boulder, CO, USA, 2009; pp. $23-42$.

27. Zaimes, G.N.; Lee, K.-H.; Tufekckioglu, M.; Long, L.A.; Schultz, R.C.; Isenhart, T.M. The effectiveness of riparian conservation practices in reducing sediment in Iowa streams. In Agricultural Research Updates; Hendriks, B., Ed.; Nova Science Publishers, Inc.: Hauppauge, NY, USA, 2011; Volume 2, pp. 117-166.

28. Knox, J.C. Floodplain sedimentation in the Upper Mississippi Valley: Natural versus human accelerated. Geomorphology 2006, 79, 286-310. [CrossRef] 
29. Simon, A.; Klimetz, L. Relative magnitudes and sources of sediment in benchmark watersheds of the Conservation Effects Assessment Project. J. Soil Water Conserv. 2008, 63, 504-522. [CrossRef]

30. Wilson, C.G.; Kuhnle, R.A.; Bosch, D.D.; Steiner, J.L.; Starks, P.J.; Tomer, M.D.; Wilson, G.V. Quantifying relative contributions from sediment sources in Conservation Effects Assessment Project watersheds. J. Soil Water Conserv. 2008, 63, 523-532. [CrossRef]

31. Belmont, P.; Gran, K.B.; Schottler, S.P.; Wilcock, P.R.; Day, S.S.; Jennings, C.; Lauer, J.W.; Viparelli, E.; Willenbring, J.K.; Engstrom, D.R.; et al. Large shift in source of fine sediment in the upper Mississippi River. Environ. Sci. Technol. 2011, 45, 8804-8810. [CrossRef]

32. Batalla, R.J.; Gomez, C.M.; Kondolf, G.M. Reservoir-induced hydrological changes in the Ebro River basin (NE Spain). J. Hydrol. 2004, 290, 117-136. [CrossRef]

33. Vanacker, V.; Molina, A.; Govers, G.; Poesen, J.; Dercon, G.; Deckers, S. River channel response to short-term human-induced change in landscape connectivity in Andean ecosystems. Geomorphology 2005, 72, 340-353. [CrossRef]

34. Wellmeyer, J.L.; Slattery, M.C.; Phillips, J.D. Quantifying downstream impacts of impoundment on flow regime and channel planform, lower Trinity River, Texas. Geomorphology 2005, 69, 1-13. [CrossRef]

35. Burkart, M.R.; Oberle, S.L.; Hewitt, M.J.; Pickus, J. A framework for regional agro-ecosystems characterization using the national resources inventory. J. Environ. Qual. 1994, 23, 866-874. [CrossRef]

36. Whitney, G.G. From Coastal Wilderness to Fruited Plains: A History of Environmental Change in Temperate North America, 1500 to Present; Cambridge University Press: Cambridge, UK, 1994.

37. Simon, A.; Rinaldi, M.; Hadish, G. Channel Evolution in the Loess Area of the Midwestern United States. In Proceedings of the Sixth Federal Interagency Sedimentation Conference, Las Vegas, NV, USA, 10-14 March 1996; U.S. Government Printing Office: Washington, DC, USA, 1996; pp. III.86-III.93.

38. Knox, J.C. Agricultural influence on landscape sensitivity in the Upper Mississippi River Valley. Catena 2001, 42, 193-224. [CrossRef]

39. Strahler, A.N. Quantitative analysis of watershed geomorphology. Trans. Am. Geophys. Union 1957, 38, 913-920. [CrossRef]

40. Zaimes, G.N.; Schultz, R.C.; Isenhart, T.M. Stream bank erosion adjacent to riparian forest buffers, row-cropped fields, and continuously-grazed pastures along Bear Creek in central Iowa. J. Soil Water Conserv. 2004, 59, 19-27.

41. Zaimes, G.N.; Schultz, R.C.; Isenhart, T.M. Riparian land-uses and precipitation influences on stream bank erosion in central Iowa. J. Am. Water Resour. Assoc. 2006, 42, 83-97. [CrossRef]

42. Zaimes, G.N.; Schultz, R.C. Riparian land-use impacts on bank erosion and deposition of an incised stream in north-central Iowa, USA. Catena 2015, 125, 61-73. [CrossRef]

43. Palmer, J.A. An Assessment of Riparian Land-Use and Channel Condition Impacts on Streambank Eroding Lengths and Recession Rates in Two Third Order Rural Watersheds in Central Iowa. Master's Thesis, Iowa State University, Ames, IA, USA, 2008.

44. Tufekcioglu, M. Stream Bank Soil and Phosphorus Losses within Grazed Pasture Stream Reaches in the Rathbun Watershed in Southern Iowa. Ph.D. Thesis, Iowa State University, Ames, IA, USA, 2010.

45. Tufekcioglu, M.; Isenhart, T.M.; Schultz, R.C.; Bear, D.A.; Kovar, J.L.; Russell, J.R. Stream bank erosion as a source of sediment and phosphorus in grazed pastures of the Rathbun Lake Watershed in Southern Iowa, United States. J. Soil Water Conserv. 2012, 67, 545-555. [CrossRef]

46. Zaimes, G.N.; Schultz, R.C. Stream bed substrate composition adjacent to different riparian land-uses in Iowa, USA. Ecol. Eng. 2011, 11, 1692-1699. [CrossRef]

47. Zaimes, G.N.; Schultz, R.C. Do randomly placed riparian conservation land-uses improve stream water quality in Iowa, USA? Pol. J. Environ. Stud. 2011, 20, 1083-1092.

48. Zaimes, G.N.; Schultz, R.C. Assessing riparian conservation land management practice impacts on gully erosion in Iowa. Environ. Manag. 2012, 49, 1009-1021. [CrossRef]

49. Zaimes, G.N.; Schultz, R.C.; Isenhart, T.M. Streambank soil and phosphorus losses under different riparian land-uses in Iowa. J. Am. Water Resour. Assoc. 2008, 42, 935-947. [CrossRef]

50. Zaimes, G.N.; Schultz, R.C.; Tufekcioglu, M. Gully and stream bank erosion in three pastures with different management in Southeast Iowa. J. Iowa Acad. Sci. 2009, 116, 1-8. 
51. Tufekcioglu, M.; Schultz, R.C.; Isenhart, T.M.; Zaimes, G.N.; Tufekcioglu, A. Riparian grazing impacts on stream bank erosion and phosphorus loss via surface runoff. J. Am. Water Resour. Assoc. 2013, 49, 103-113. [CrossRef]

52. USDA-NRCS (United States Department of Agriculture-Natural Resources Conservation Service). Riparian Forest Buffer; Conservation Practice Standard, Code 391; USDA-NRCS: Des Moines, IA, USA, 1997.

53. USDA-NRCS (United States Department of Agriculture-Natural Resources Conservation Service). Grass Filters; Conservation Practice Standard, Code 393; USDA-NRCS: Des Moines, IA, USA, 1997.

54. USDA-NRCS (United States Department of Agriculture-Natural Resources Conservation Service). Profitable Pastures: A Guide to Grass, Grazing and Good Management; USDA-NRCS: Des Moines, IA, USA, 1997.

55. Lawler, D.M. The measurement of river bank erosion and lateral channel change: A review. Earth Surf. Process. Landf. 1993, 18, 777-821. [CrossRef]

56. Kearney, S.P.; Fonte, S.J.; Garcia, E.; Smukler, S.M. Improving the utility of erosion pins: Absolute value of pin height change as an indicator of relative erosion. Catena 2018, 163, 427-432. [CrossRef]

57. USDA-NRCS (United States Department of Agriculture-Natural Resources Conservation Service). Erosion and Sediment Delivery; Field Office Technical Guide Notice no. IA-198; USDA-NRCS: Des Moines, IA, USA, 1998.

58. Lawler, D.M. A new technique for the automatic monitoring of erosion and deposition rates. Water Resour. Res. 1991, 27, 2125-2128. [CrossRef]

59. Lawler, D.M. Design and installation of a novel automatic erosion monitoring system. Earth Surf. Process. Landf. 1992, 17, 455-463. [CrossRef]

60. Lawler, D.M.; Couperthwaite, J.; Bull, L.J.; Harris, N.M. Bank erosion event and process in the Upper Severn Basin. Hydrol. Earth Syst. Sci. 1997, 1, 523-534. [CrossRef]

61. Couper, P.; Maddock, I.P. Subaerial river bank processes and interaction with other bank erosion mechanisms on the River Arrow, Warwickshire, UK. Earth Surf. Process. Landf. 2001, 26, 631-646. [CrossRef]

62. Wynn, T.M.; Mostaghimi, S. The effects of vegetation and soil type on streambank erosion, Southwestern Virginia, USA. J. Am. Water Resour. Assoc. 2006, 42, 69-82. [CrossRef]

63. Soil Science Society of America (SSSA). Glossary of Soil Science Terms. Soil Science Society of America. 2001. Available online: https://www.soils.org/publications/soils-glossary (accessed on 5 November 2010).

64. Heitke, J.D. In-stream and Riparian Habitat Relationships in Iowa Streams. Master's Thesis, Iowa State University, Ames, IA, USA, 2002.

65. APHA (American Public Health Association). Standard Methods for the Examination of Water and Wastewater; APHA: Washington, DC, USA, 1998.

66. Simonson, T.D.; Lyons, J.; Kanehl, P.D. Guidelines for Evaluating Fish Habitat in Wisconsin Streams; General Technical Report NC-164; USDA, Forest Service, North Central Forest Experiment Station: St. Paul, MN, USA, 1994.

67. Kronvang, B.; Grant, R.; Laubel, A.L. Sediment and phosphorus export from a lowland catchment: Quantification of sources. Water Air Soil Pollut. 1997, 99, 465-476. [CrossRef]

68. Simon, A.; Darby, S. The nature and significance of incised river channels. In Incised River Channels: Processes, Forms, Engineering, and Management; Darby, S.E., Simon, A., Eds.; John Wiley and Sons: Chichester, UK, 1999; pp. 1-18.

69. Pollen-Bankhead, N.; Simon, A. Hydrologic and hydraulic effects of riparian root networks on streambank stability: Is mechanical root-reinforcement the whole story? Geomorphology 2010, 116, 353-362. [CrossRef]

70. Trimble, S.W.; Mendel, A.C. The cow as a geomorphic agent-A critical review. Geomorphology 1995, 13, 233-253. [CrossRef]

71. Hadrich, J.C.; Van Winkle, A. Awareness and pro-active adoption of surface water BMPs. J. Environ. Manag. 2013, 127, 221-227. [CrossRef] [PubMed]

72. Schultz, R.C.; Isenhart, T.M.; Simpkins, W.W.; Colletti, J.P. Riparian Forest Buffers in Agroecosystems-Lessons Learned from the Bear Creek Watershed, Central Iowa, USA. Agrofor. Syst. 2004, 61, 35-50.

73. Simon, A.; Pollen-Bankhead, N.; Thomas, R.E. Development and application of a deterministic bank stability and toe erosion model for stream restoration. Geophys. Monogr. Ser. 2011, 194, 453-474.

74. Arthun, D.; Zaimes, G.N.; Martin, J. Temporal river channel changes in the Gila Box Riparian National Conservation Area, Arizona, USA. Phys. Geogr. 2013, 34, 60-73. [CrossRef]

75. Gurnell, A. Plants as river system engineers. Earth Surf. Process. Landf. 2014, 39, 4-25. [CrossRef] 
76. Purvis, R.A.; Fox, G.A. Streambank sediment loading rates at the watershed scale and the benefit of riparian protection. Earth Surf. Process. Landf. 2016, 41, 1327-1336. [CrossRef]

77. Diebel, M.W.; Maxted, J.T.; Robertson, D.M.; Han, S.; Vander Zanden, M.J. Landscape planning for agricultural nonpoint source pollution reduction III: Assessing phosphorus and sediment reduction potential. Environ. Manag. 2001, 43, 69-83. [CrossRef]

78. Díaz-Pascacio, E.; Ortega-Argueta, A.; Castillo-Uzcanga, M.M.; Ramírez-Marcial, N. Influence of land use on the riparian zone condition along an urban-rural gradient on the Sabinal River, Mexico. Bot. Sci. 2018, 96, 180-199. [CrossRef]

79. Harmel, R.D.; Haan, C.T.; Duntnell, R.C. Bank erosion and riparian vegetation influences; Upper Illinois River, Oklahoma. Trans. ASAE 1999, 42, 1321-1329. [CrossRef]

80. Lyons, J.; Weasel, B.M.; Paine, L.K.; Undersander, D.J. Influence of intensive rotational grazing on bank erosion, fish habitat quality, and fish communities in Southwestern Wisconsin trout streams. J. Soil Water Conserv. 2000, 55, 271-276.

81. Malkinson, D.; Wittenberg, L. Scaling the effects of riparian vegetation on cross-sectional characteristics of ephemeral mountain streams-A case study of Nahal Oren, Mt. Carmel, Israel. Catena 2007, 69, 103-110. [CrossRef]

82. Hagerty, D.J.; Spoor, M.F.; Ullrich, C.R. Bank failure and erosion on the Ohio River. Eng. Geol. 1981, 17, 141-158. [CrossRef]

83. Wynn, T.M.; Henderson, M.B.; Vaughan, D.H. Changes in streambank erodibility and critical shear stress due to subaerial processes along a headwater stream, southwestern Virginia, USA. Geomorphology 2008, 97, 260-273. [CrossRef]

84. Simon, A.; Rinaldi, M. Channel instability in the loess area of the midwestern United States. J. Am. Water Resour. Assoc. 2000, 36, 133-150. [CrossRef]

85. Henshaw, A.J.; Thorne, C.R.; Clifford, N.J. Identifying causes and controls of river bank erosion in a British upland catchment. Catena 2012, 100, 107-119. [CrossRef]

86. Sharpley, A.N.; Foy, R.H.; Withers, P.J.A. Practical and innovative measures for the control of agricultural phosphorus losses to water: An overview. J. Environ. Qual. 2000, 29, 1-9. [CrossRef]

87. Gomez, B.; Banbury, K.; Marden, M.; Trustrum, N.A.; Peacock, D.H.; Hoskin, P.J. Gully erosion and sediment production: Te Weraroa Stream, New Zealand. Water Resour. Res. 2003, 39, 1187. [CrossRef]

88. Dabney, S.M.; Shields, F.D., Jr.; Temple, D.M.; Langendoen, E.J. Erosion processes in gullies modified by establishing grass hedges. Trans. ASAE 2004, 47, 1561-1571. [CrossRef]

89. Ayele, G.K.; Addisie, M.B.; Langendoen, E.J.; Tegegne, N.H.; Tilahun, S.A.; Moges, M.A.; Nicholson, C.F.; Steenhuis, T.S. Evaluating erosion control practices in an actively gullying watershed in the highlands of Ethiopia. Earth Surf. Process. Landf. 2018, 43, 2835-2843. [CrossRef]

90. Sharpley, A.N.; Daniel, T.; Sims, J.T.; Lemunyon, J.; Stevens, R.; Parry, R. Agricultural Phosphorus and Eutrophication, 2nd ed.; USDA-ARS: Washington, DC, USA, 2003.

91. McDowell, R.W.; Srinivasan, M.S. Identifying critical source areas to water quality: 2. Validating the approach for phosphorus and sediment losses in grazed headwater catchments. J. Hydrol. 2009, 379, 68-80. [CrossRef]

92. Wohl, N.E.; Carline, R.F. Relations among riparian grazing, sediment loads, macroinvertebrates, and fishes in three central Pennsylvania streams. Can. J. Fish. Aquat. Sci. 1996, 53, 260-266. [CrossRef]

93. Li, J.-F.; Tfwala, S.S.; Chen, S.-C. Effects of Vegetation Density and Arrangement on Sediment Budget in a Sediment-Laden Flow. Water 2018, 10, 1412. [CrossRef]

94. Wilton, T.F. Biological Assessment of Iowa's Wadeable Streams; Iowa DNR: Des Moines, IA, USA, 2004.

95. Heitke, J.D.; Pierce, C.L.; Gelwicks, G.T.; Simmons, G.A.; Siegwarth, G.L. Habitat land use, and fish assemblage relationships in Iowa streams: Preliminary assessment in an agricultural landscape. In Influences of Landscape on Stream Habitat and Biological Communities; Wang, L., Hughes, R., Seelbach, P.W., Eds.; American Fisheries Society: Bethesda, MD, USA, 2006; pp. 287-303.

96. Banner, E.B.K.; Stahl, A.J.; Dodds, W.K. Stream discharge and riparian land use influence in-stream concentrations and loads of phosphorus from Central Plains watersheds. Environ. Manag. 2009, 44, 552-565. [CrossRef] [PubMed]

97. Njue, N.; Koech, E.; Hitimana, J.; Sirmah, P. Influence of land use activities on riparian vegetation, soil and water quality: An indicator of biodiversity loss, South West Mau Forest, Kenya. Open J. For. 2016, 6, $373-385$. [CrossRef] 
98. Lawler, D.M. Defining the moment of erosion: The principle of thermal consonance timing. Earth Surf. Process. Landf. 2005, 30, 1597-1615. [CrossRef]

99. Zaimes, G.N.; Iakovoglou, V.; Koutalakis, P.; Ioannou, K.; Kosmadakis, I.; Tsardaklis, P.; Laopoulos, P. The automated soil erosion monitoring system (ASEMS). Int. J. Geol. Environ. Eng. 2015, 9, 1249-1252.

(C) 2019 by the authors. Licensee MDPI, Basel, Switzerland. This article is an open access article distributed under the terms and conditions of the Creative Commons Attribution (CC BY) license (http://creativecommons.org/licenses/by/4.0/). 